\title{
Synchronous drying and cooling in central Asia during late Oligocene
}

\author{
DONG XinXin ${ }^{1,2^{*}}$, DING ZhongLi ${ }^{1}$, YANG ShiLing ${ }^{1}$, LUO Pan ${ }^{3}$, WANG Xu ${ }^{1} \&$ JI JunLiang ${ }^{4}$ \\ ${ }^{1}$ Key Laboratory of Cenozoic Geology and Environment, Institute of Geology and Geophysics, Chinese Academy of Sciences, \\ Beijing 100029, China; \\ ${ }^{2}$ University of Chinese Academy of Sciences, Beijing 100049, China; \\ ${ }^{3}$ Petroleum Geology Research and Laboratory Center, Research Institute of Petroleum Exploration and Development, PetroChina, \\ Beijing 100083, China; \\ ${ }^{4}$ Key Laboratory of Biogeology and Environmental Geology of Ministry of Education, China University of Geosciences, Wuhan 430074, China
}

Received December 31, 2012; accepted March 4, 2013; published online April 12, 2013

\begin{abstract}
Aridification of central Asia during late Oligocene and Early Miocene has been documented by numerous eolian records from the North Pacific and central Asia. However, direct evidence of aridity from the interior of the arid zone is still rather scarce. To better reconstruct the climate history in central Asia during the late Oligocene, we have analyzed ostracod assemblages and gypsum content in the sediments from the lacustrine Jingou River section in the northern Tianshan Mountains. Our results show that the cold water species Candona cf. Neglecta and Pseudocandona albicans replaced the warm water species Ilyocypris bradyi and Ilyocypris sp. to become the dominant species at $23.8 \mathrm{Ma}$, indicating significant cooling in central Asia at that time. At the same time, a substantial increase in gypsum content indicates the intensification of central Asian drying. The synchronous cooling and drying approximately coincided with the Oi2b.1 and/or Mi1 events, implying a causal linkage between late Oligocene global cooling and central Asian aridity.
\end{abstract}

central Asian aridification, cooling, ostracod, gypsum, Oligocene, Jingou River section

Citation: Dong X X, Ding Z L, Yang S L, et al. Synchronous drying and cooling in central Asia during late Oligocene. Chin Sci Bull, 2013, 58: 3119-3124, doi: $10.1007 / \mathrm{s} 11434-013-5821-3$

Central Asia is the largest inland arid region in the midlatitudes on Earth. Eolian records in deep-sea sediments [1,2] and dust deposits from the periphery of arid regions $[3,4]$ have shown that central Asian aridity began to intensify from the late Oligocene to the early Miocene. Eolian deposits within central Asian arid regions [5] have implied that an arid pattern similar to that of today may have formed before the late Oligocene. However, these interpretations based on eolian deposits can be regarded as only indirect evidence because the processes of dust transport and sedimentation have been affected by locally varying factors such as geomorphological conditions, the configuration of loess-desert distribution, and wind trajectories [6-9]. Therefore, to understand the late Oligocene climate history of the central

*Corresponding author (email: xxdong@mail.iggcas.ac.cn)
Asian arid region, direct evidence from the arid region is particularly important. Such evidence is relatively scarce at this point.

Recently, a palynological record from the Jingou River section in the Junggar Basin of the northern Tianshan Mountains [10] revealed that aridity began to intensify during the late Oligocene. This record provided direct evidence of inland aridification, but multiple proxies need to be analyzed to better understand the history of climate change in central Asia. The Jingou River section is composed of a sequence of nearly consecutive, green-colored lacustrine sediments spanning the late Oligocene. Non-marine ostracod assemblages have been considered good indicators of paleoenvironmental conditions, especially in lacustrine sediments, because they are sensitive to water temperature and chemistry [11,12]. In this paper, we have studied fossil, 
non-marine ostracods and gypsum content in the section. We have then combined the ostracod assemblage and gypsum content with the pollen record [10] to reconstruct the climate history during the late Oligocene and try to explore the causal linkage between central Asian aridity and global cooling.

\section{Geological setting}

The Jingou River section is located in the heart of the central Asian arid region (Figure 1) and close to the sedimentation center of Mesozoic to Neogene deposition on the north pediment of the Tianshan Mountains [13]. Thick Cenozoic sediments were deformed into east-west fold-thrust belts that are made up of linear anticlines. The Jingou River formed a perpendicular incision through the center of the Huoerguosi Anticline. The Jingou River section is exposed on the southern limb of the anticline and consists of the Anjihaihe, Shawan, Taxihe, Dushanzi and Xiyu formations from the core to the south [14].

The Anjihaihe Formation in the Jingou River section was selected for this study. The strata in this formation are above the boundary of the thrust fault, underlying the Shawan Formation with a conformable contact [14]. While sediment lithology is primarily gray-green mudstone in the total $200 \mathrm{~m}$ of strata, the lower part $(0-67 \mathrm{~m})$ contains a small amount of thin layers of plaster, the middle to the upper part (67-181 m) contains gray-black shale, thin layers of gray-white marl and, rarely, yellowish-brown siltstone bands, and the top part (181-200 m) in the Anjihaihe formation is characterized by the alternation of gypsum and mudstone layers and no traversing-layer phenomena was observed. Magnetostratigraphic analysis has shown that the Anjihaihe Formation covered the interval from 28.0 to 23.3 Ma [10] (Figure 1).

\section{Materials and methods}

All of the ostracod samples were collected from green lacustrine mudstone in the Anjihaihe Formation. Ostracod sampling was designed to produce a temporal resolution of $25 \mathrm{ka}$ or less per sample. The timescale of our samples was established by linear interpolation between magnetostratigraphic age control points. A total of 200 samples in the Anjihaihe Formation were analyzed.

The extraction of fossil ostracod valves followed the peroxide method described by Zhai et al. [15]. We identified ostracods in the samples according to the taxonomy of

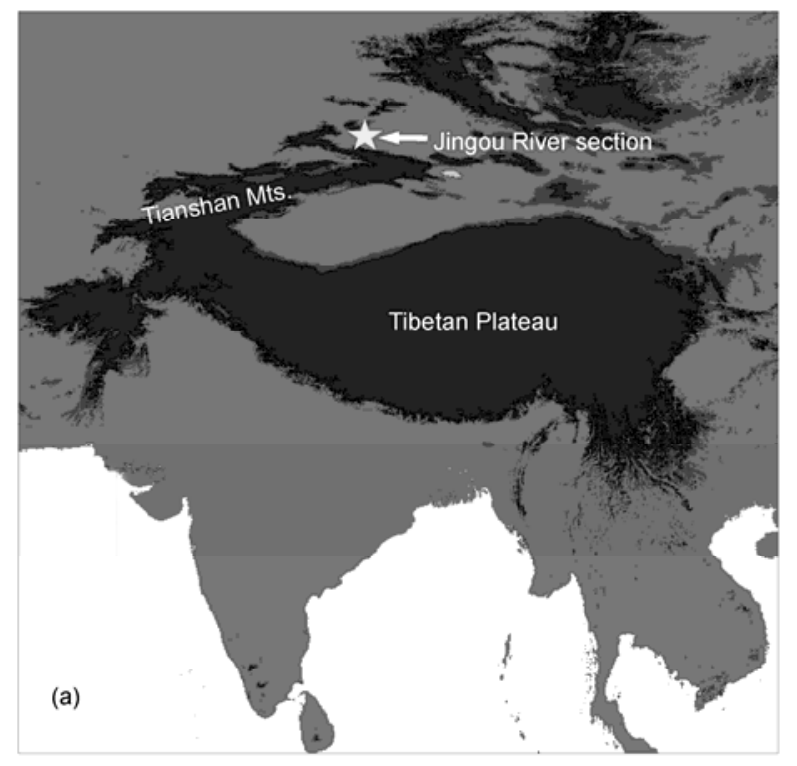

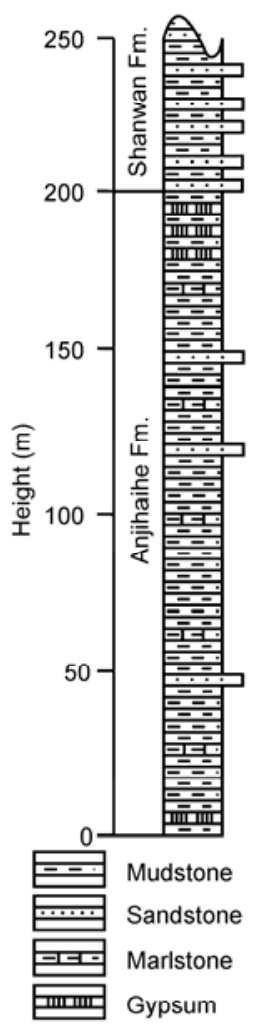

(c)

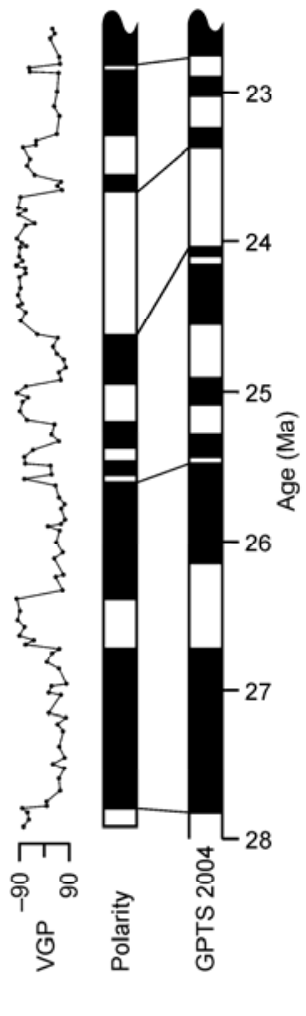

(d)

Figure 1 General information about the Jingou River section. (a) Location of the section; (b) photo of the Anjihaihe Formation; (c) lithology of the Anjihaihe Formation; (d) magnetostratigraphic age model of the Anjihaihe Formation [10]. 
Jiang et al. [16], Meisch [17] and Hou et al. [18]. Candoniella albicans was identified as Pseudocandona albicans, following Meisch [17]. Stratigraphically constrained cluster analysis (CONISS [19]) was used to divide the ostracod abundance diagram of the Anjihaihe formation into ostracod assemblage zones based on the number of each species of fossil ostracod. In addition, gypsum content was determined using the rapid detection method [20] in the Anjihaihe formation sample sequence.

\section{Results}

Of the 200 samples from the Anjihaihe Formation, only 98 samples contained fossil ostracods. A total of 6015 valves were picked from the 98 samples, and 16 species of ostracods belonging to 11 genera were identified. These species were Ilyocypris bradyi, Ilyocypris cornea, Ilyocypris sp., Hemicyprideis intercedens, Hemicyprideis rhenana, Cypris magnifica, Eucypris ignis, Eucypris notabilis, Eucypris profundis, Kassinina beliaevskyi, Heterocypris subsinuatus, Candona cf. neglecta, Candoniella marcida, Pseudocandona albicans, Cypria schichoensis and Cyprinotus tutunchous.

The ostracod abundance diagram of the Anjihaihe Formation was subdivided into three ostracod assemblage zones based on the stratigraphically constrained cluster analysis (CONISS [19]). The record of gypsum content in the sequence corresponds well with these ostracod assemblage zones (Figure 2).
Zone 1 (28.0-26.4 Ma, 0-67 m). Ilyocypris bradyi, Ilyocypris cornea and Ilyocypris sp. were the dominant species, while Cypris magnifica appeared piecemeal in this zone. Additionally, Hemicyprideis intercedens and Hemicyprideis rhenana were found at $59 \mathrm{~m}(-26.63 \mathrm{Ma})$. Fossil ostracod concentration was 31 valves per 100 grams on average. Gypsum content fluctuated between $8.2 \%$ and $19.4 \%$, with a mean value of $16.8 \% \pm 2.6 \%$.

Zone 2 (26.4-23.8 Ma, 67-181 m). Ilyocypris bradyi, Ilyocypris cornea and Ilyocypris sp. were still the prevailing species in this zone. Six other species, i.e. Cypris magnifica, Eucypris ignis, Eucypris notabilis, Eucypris profundis, Kassinina beliaevskyi and Heterocypris subsinuatus, appeared occasionally. Fossil ostracod concentration was 78 valves per 100 grams on average. Gypsum content varied between $9.0 \%$ and $19.4 \%$, with a mean value of $13.4 \% \pm 2.1 \%$.

Zone 3 (23.8-23.3 Ma, 181-200 m). Candona cf. neglecta, Candoniella marcida, Pseudocandona albicans, Cypria schichoensis, Cyprinotus tutunchous, Eucypris ignis and Kassinina beliaevskyi prospered in this zone, while Ilyocypris bradyi, Ilyocypris cornea and Ilyocypris sp. became extinct. Fossil ostracod concentration was 45 valves per 100 grams on average. Gypsum content ranged from $19.0 \%$ to $96.6 \%$, with a mean value of $62.5 \% \pm 13.1 \%$.

\section{Discussions}

The occurrence of ostracod species is related to the salinity and/or temperature of the host water [17]; hence, the

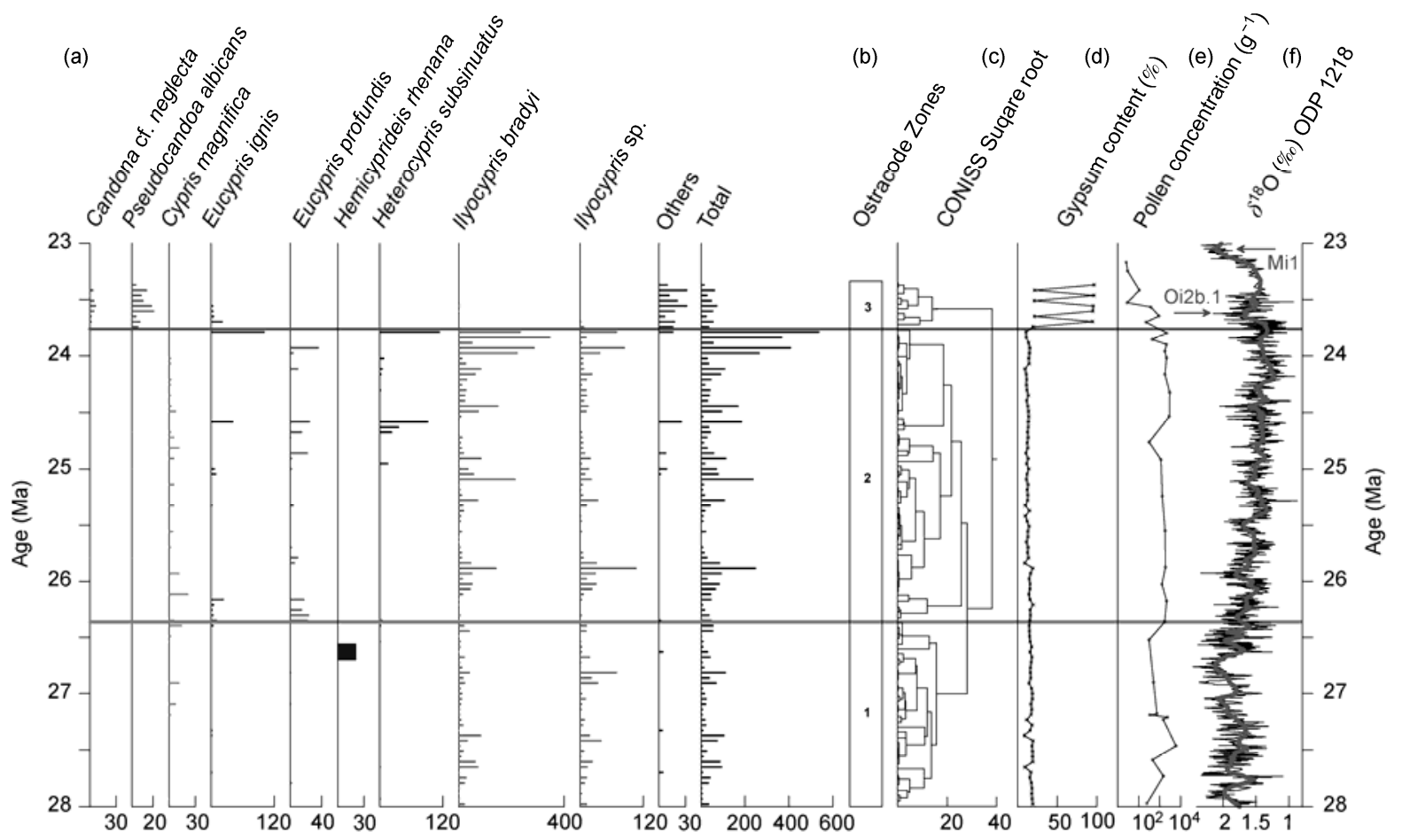

Figure 2 (a) Ostracod assemblages; (b) Ostracod zones; (c) CONISS; (d) gypsum content; (e) pollen concentrations [10]; (f) ODP $1218 \delta^{18} \mathrm{O}$ of benthic foraminifera [21]. 
environmental requirements of living and fossil taxa found in the Anjihaihe Formation can be utilized to draw conclusions regarding the environmental conditions prevailing during the past [11]. Ilyocypris bradyi prefers warm water and lives in wide temperature range [22], but shows very low abundance in cool water body [23], it tolerates salinity up to $4.5 \%$ [17], thus we consider that high concentration of I. bradyi may indicate warm, fresh water. Hemicyprideis intercedens and Hemicyprideis rhenana, which are fossil species, are considered to be brackish or salty types [24]. Pseudocandona albicans lives in shallow lakes, ponds and other bodies of water, has a bias towards cold water temperature $[11,25]$ and has a salinity tolerance up to 5.5\%o [26]. Extant records of Pseudocandona albicans reported in recent years were mainly from areas with low mean annual temperatures or areas where cold water was directly injected, such as Alpine foothill lakes [27], the Qaidam Basin [28] and Hulun Lake [29]. Candona neglecta is always found in cold host water, with a salinity range of $0.5 \%$ - $16 \%$ [ [17].

The ostracod assemblage recovered from the Anjihaihe formation indicates qualitative changes in water temperature and salinity. Gypsum content in the river section indicates hydrogeological processes of the saline water [30]. These two proxies together with the pollen sequence [10] thus reveal a detailed climate change history in the area during the late Oligocene.

From 28 to $26.4 \mathrm{Ma}$, the dominance of Ilyocypris bradyi and Ilyocypris sp. indicates warm, fresh to brackish host water. The occurrence of salty species Hemicyprideis intercedens and Hemicyprideis rhenana reflect brackish to salty water. These four species thus show that the aquatic environment was warm and brackish. Low gypsum content in this interval indicates low salinity in this water body. The pollen records are mainly composed of Cyatheaceae, Quercus, Labiatae, Pinus and Ephedra in this band [10]. All three proxies together indicate that the climate was warm and semi-humid during this period.

From 26.4 to $23.8 \mathrm{Ma}$, high concentrations of warm species Ilyocypris bradyi and Ilyocypris sp. indicate a temperature maximum in this period. Salty water ostracods disappeared, indicating a decline in salinity of the host water. The minimum gypsum content in this band also reflects a salinity minimum in the host water. Cyatheaceae, Potamogetonacea and Sparganiaceae increased, while Pinus and Ephedra decreased in the pollen records [10]. We infer that the climate became warmer and more humid than that of the previous period.

From 23.8 to $23.3 \mathrm{Ma}$, the cold-water species Candona cf. neglecta and Pseudocandona albicans completely replaced warm-water species, indicating a significant decline in water temperature. Lithology in this zone is interbedded with grey-green mudstone and yellowish gypsum layers. The mean gypsum content reached up to more than $60 \%$, the highest value of the whole formation, which shows a remarkable rise in water salinity. Xerophytic herbs Artemi- sia and Chenopodiaceae gradually occupied the region, and pollen flux and concentration observably decreased [10]. These proxies suggest that terrestrial cooling and drying may have occurred starting at $23.8 \mathrm{Ma}$.

In summary, ostracod assemblage, gypsum content and pollen records consistently show a significant drying at 23.8 $\mathrm{Ma}$ in central Asian arid regions. This finding not only provides direct evidence of late Oligocene aridification in central Asia, but it also explains speculations of central Asian aridification based on eolian records, such as the appearance of dust deposition in the Junggar Basin [5] and the Loess Plateau [4] during the late Oligocene and the doubling of North Pacific eolian flux from the Eurasian continent during the same period $[1,2]$.

Although numerous studies have linked central Asian aridity with regional tectonism [31-34], an increasing amount of evidence has shown a direct linkage of central Asian aridity to global cooling [35,36]. Worldwide glacial events Oi2b.1 and Mi1 occurred between 24 and 23 Ma, near the Oligocene/Miocene boundary. The Oi2b.1 event was recorded by $\delta^{18} \mathrm{O}$ of benthic foraminifera in ODP Sites 1090 [37] and 1218 [21], and the Mi1 event was identified in benthic foraminiferal $\delta^{18} \mathrm{O}$ in DSDP Sites 522, 529, 563 and 608 [38], and in ODP Sites 926, 929 [39], 1090 [37], 1218 and 1219 [40]. With ongoing interpretation of isotopic indicators and the development of new proxies, details of the Oi2b.1 and Mi1 events have been gradually revealed. Of the $1 \%$ o shift in $\delta^{18} \mathrm{O}$ at ODP Site $929,0.5 \%$ o was likely due to ice-volume effects, and the remaining $0.5 \%$ o resulted from a $2^{\circ} \mathrm{C}$ cooling of bottom waters [41]. Peak $\delta^{18} \mathrm{O}$ values and a 2 -step increase in $\delta^{18} \mathrm{O}$ before the peak Mi1 $\delta^{18} \mathrm{O}$ values at ODP Site 1218 represent a significant rise in continental ice-volume, and a rapid decrease in $\mathrm{Mg} / \mathrm{Ca}$ ratios during 23.1-23.0 Ma indicates a $2^{\circ} \mathrm{C}$ cooling of Pacific Bottom Water [21]. Coral-zooxanthellate in the Mediterranean also indicates that SST decreased near the Oligocene/Miocene boundary [42]. Meanwhile, continental areas likewise underwent significant climate change during Oi2b.1 and Mi1. The palynological record of the Cape Roberts Drillhole CRP-2/2A in the Victoria Land Basin in Antarctica shows a cooling trend in the summer temperatures from the late Oligocene to the early Miocene [43], and the Drillhole CRP-2 recorded the expansion of the Antarctic ice sheet during Mi1 [44]. Temperatures and precipitation levels reconstructed using flora assemblages in central Europe also decreased during 24-23 Ma [45]. In summary, both marine and terrestrial records have congruously proven the global cooling and ice-volume increase during 24-23 Ma.

Atmospheric vapor pressure obeys the ClausiusClaperyon equation at different temperatures. Theoretically, the saturation vapor pressure decreases by approximately $7 \%$ for each $1 \mathrm{~K}$ (or ${ }^{\circ} \mathrm{C}$ ) decrease in temperature, and the simulated precipitation decreases by approximately $2.2 \%$ for each $1 \mathrm{~K}$ (or ${ }^{\circ} \mathrm{C}$ ) decrease in temperature. These theo- 
retical relationships are comparable with the results of actual observations in the last 20 years of the 20th century [46]. Based on the above theory and observations, we speculate that when temperatures dropped in the Atlantic and the Mediterranean regions during 24-23 Ma, water evaporation decreased, thus reducing the capacity of the atmosphere to hold water. Consequently, westerly circulation transported less water vapor to Eurasia, which might explain the decrease in temperature and precipitation in central Europe during this period [45]. Similarly, cooling and drying in central Asia near 23.8 Ma may imply that global cooling during Oi2b.1 and Mi1 possibly caused late Oligocene central Asian aridification.

This work was supported by the Strategic Priority Research Program of the Chinese Academy of Sciences (XDB03020503), the National Basic Research Program of China (2013CB956404), and the National Natural Science Foundation of China (40902049). We thank Prof. Sun Zhencheng of China University of Petroleum for help with identification of ostracode fossils, and Drs. Zhai Dayou and Tang Zihua of Institute of Geology and Geophysics, Chinese Academy of Sciences for valuable comments and suggestions. The comments and suggestions of two anonymous reviewers significantly improved this manuscript and their efforts are greatly appreciated.

1 Rea D K, Leinen M, Janecek T R. Geologic approach to the longterm history of atmospheric circulation. Science, 1985, 227: 721-725

2 Ziegler C, Murray R, Hovan S, et al. Resolving eolian, volcanogenic, and authigenic components in pelagic sediment from the Pacific Ocean. Earth Planet Sci Lett, 2007, 254: 416-432

3 Guo Z, Ruddiman W F, Hao Q, et al. Onset of Asian desertification by $22 \mathrm{Myr}$ ago inferred from loess deposits in China. Nature, 2002, 416: $159-163$

4 Qiang X K, An Z S, Song Y G, et al. New eolian red clay sequence on the western Chinese Loess Plateau linked to onset of Asian desertification about 25 Ma ago. Sci China Ser D-Earth Sci, 2011, 54: 136-144

5 Sun J, Ye J, Wu W, et al. Late Oligocene-Miocene mid-latitude aridification and wind patterns in the Asian interior. Geology, 2010, 38: $515-518$

6 Liu T S. Loess and the Environment (in Chinese). Beijing: China Ocean Press, 1985

7 Ding Z, Derbyshire E, Yang S, et al. Stacked 2.6-ma grain size record from the Chinese loess based on five sections and correlation with the deep-sea $\delta^{18} \mathrm{O}$ record. Paleoceanography, 2002, 17: 5-1-5-21

8 Yang S, Ding Z. Advance-retreat history of the East-Asian summer monsoon rainfall belt over northern China during the last two glacialinterglacial cycles. Earth Planet Sci Lett, 2008, 274: 499-510

9 Yang S, Ding Z. Comparison of particle size characteristics of the Tertiary 'red clay' and pleistocene loess in the Chinese Loess Plateau: Implications for origin and sources of the 'red clay'. Sedimentology, 2004, 51: 77-93

10 Tang Z, Ding Z, White P D, et al. Late Cenozoic central Asian drying inferred from a palynological record from the northern Tian Shan. Earth Planet Sci Lett, 2011, 302: 439-447

11 Wilkinson I, Bubikyan S, Gulakyan S. The impact of late Holocene environmental change on lacustrine Ostracoda in Armenia. Palaeogeogr Palaeoclimatol Palaeoecol, 2005, 225: 187-202

12 Griffiths H I, Holmes J. Non-marine Ostracods and Quaternary Palaeoenvironments. London: Quaternary Research Association, 2000

13 Xinjiang Institute of Geography Chinese Academy of Sciences. The Evolution of the Tianshan Mountains (in Chinese). Beijing: Science Press, 1986
14 Li Y T. The Tertiary System of China (in Chinese). Beijing: Geological Publishing House, 1984

15 Zhai D, Xiao J, Zhou L, et al. Similar distribution pattern of different phenotypes of Limnocythere inopinata (Baird) in a brackish-water lake in Inner Mongolia. Hydrobiologia, 2010, 651: 185-197

16 Jiang X T, Zhou W F, Lin S P. Stratigraphy and Ostracods of Xinjiang in China (in Chinese). Beijing: Geological Publishing House, 1995

17 Meisch C. Freshwater Ostracoda of Western and Central Europe. Heidelberg·Berlin: Spektrum Akademischer Verlag, 2000

18 Hou Y T, Gou Y X, Chen D Q. Fossil Ostracoda of China (Vol. 1) (in Chinese). Beijing: Science Press, 2002

19 Grimm E C. Coniss: A fortran 77 program for stratigraphically constrained cluster analysis by the method of incremental sum of squares. Comput Geosci, 1987, 13: 13-35

20 Nelson R, Klameth L, Nettleton W. Determining soil gypsum content and expressing properties of gypsiferous soils. Soil Sci Soc Am J, 1978, 42: 659-661

21 Lear C H, Rosenthal Y, Coxall H K, et al. Late Eocene to early Miocene ice sheet dynamics and the global carbon cycle. Paleoceanography, 2004, 19: PA4015

22 Vesper B. Ein beitrag zur ostracodenfauna schleswig-holsteins. Mitteilungen aus dem hamburgischen Zoologischen Museum und Institut, 1975, 72: 97-108

23 Zhang $\mathrm{H} \mathrm{C}$. Ostracod assemblages and their paleoenvironmental significance from shell bar section of paleolake Qarhan, Qaidam Basin (in Chinese). Quat Sci, 2008, 28: 103-111

24 Gebhardt H. Palaeobiogeography of Late Oligocene to Early Miocene Central European Ostracoda and Foraminifera: Progressive isolation of the Mainz Basin, northern Upper Rhine Graben and Hanau Basin/ Wetterau. Palaeogeogr Palaeoclimatol Palaeoecol, 2003, 201: 343354

25 Danielopol D L. Sur la biologie de quelques ostracodes candoninae épigés et hypogés d'Europe. Bull Museum Nat Hist Nat Paris, 1980, 4: 471-506

26 Hiller D. Untersuchungen zur biologie und zur kologie limnischer ostracoden aus der umgebung von hamburg. Archiv Hydrobiol, 1972, Supplement-Band 40: 400-497

27 Danielopol D. Spatial distribution and dispersal of interstitial Crustacea in alluvial sediments of a backwater of the Danube at Vienna. Stygologia, 1991, 6: 97-110

28 Yang F, Qiao Z Z, Zhang H Q, et al. Features of the Cenozoic ostracod fauna and environmental significance in Qaidam Basin (in Chinese). J Palaeogeogr, 2006, 8: 143-156

29 Zhai D, Xiao J, Zhou L, et al. Holocene East Asian monsoon variation inferred from species assemblage and shell chemistry of the ostracodes from Hulun Lake, Inner Mongolia. Quat Res, 2011, 75: 512-522

30 Yechieli Y, Wood W W. Hydrogeologic processes in saline systems: Playas, sabkhas, and saline lakes. Earth Sci Rev, 2002, 58: 343-365

31 Manabe S, Broccoli A. Mountains and arid climates of middle latitudes. Science, 1990, 247: 192-195

32 Kutzbach J, Prell W, Ruddiman W F. Sensitivity of Eurasian climate to surface uplift of the Tibetan Plateau. J Geol, 1993, 177-190

33 Zhang Z, Wang $\mathrm{H}$, Guo Z, et al. Impacts of tectonic changes on the reorganization of the Cenozoic paleoclimatic patterns in China. Earth Planet Sci Lett, 2007, 257: 622-634

34 Guo Z, Sun B, Zhang Z, et al. A major reorganization of Asian climate by the early Miocene. Clim Past, 2008, 4: 153-174

35 Dupont-Nivet G, Krijgsman W, Langereis C G, et al. Tibetan Plateau aridification linked to global cooling at the Eocene-Oligocene transition. Nature, 2007, 445: 635-638

36 Lu H, Wang X, Li L. Aeolian sediment evidence that global cooling has driven late Cenozoic stepwise aridification in central Asia. Geol Soc Lond Spec Publ, 2010, 342: 29-44

37 Billups K, Channell J E T, Zachos J. Late Oligocene to early Miocene geochronology and paleoceanography from the subantarctic South Atlantic. Paleoceanography, 2002, 17: 4-1-4-11

38 Miller K G, Wright J D, Fairbanks R G. Unlocking the ice house: 
Oligocene-Miocene oxygen isotopes, eustasy, and margin erosion. J Geophys Res, 1991, 96: 6829-6848

39 Flower B P, Zachos J C, Martin E. Latest Oligocene through early Miocene isotopic stratigraphy and deep-water paleoceanography of the western Equatorial Atlantic: Sites 926 and 929. In: Shackleton N J, Curry W B, Richter C, et al. College Station, TX: Ocean Drilling Program, 1997. 451-462

40 Tripati A, Elderfield H, Booth L, et al. Data report: High-resolution benthic foraminiferal stable isotope stratigraphy across the Oligocene/Miocene boundary at site 1218. In: Wilson P, Lyle M, Firth J. College Station, TX: Ocean Drilling Program, 2006. 1-13

41 Paul H, Zachos J, Flower B, et al. Orbitally induced climate and geochemical variability across the Oligocene/Miocene boundary. Paleoceanography, 2000, 15: 471-485
42 Bosellini F R, Perrin C. Estimating mediterranean OligoceneMiocene sea-surface temperatures: An approach based on coral taxonomic richness. Palaeogeogr Palaeoclimatol Palaeoecol, 2008, 258: $71-88$

43 Askin R, Raine J. Oligocene and early Miocene terrestrial palynology of the Cape Roberts Drillhole CRP-2/2A, Victoria Land Basin, Antarctica. Terra Antartica, 2000, 7: 493-501

44 Naish T, Woolfe K, Barrett P, et al. Orbitally induced oscillations in the East Antarctic ice sheet at the Oligocene/Miocene boundary. Nature, 2001, 413: 719-723

45 Mosbrugger V. Cenozoic continental climatic evolution of Central Europe. Proc Natl Acad Sci USA, 2005, 102: 14964-14969

46 Held I M, Soden B J. Robust responses of the hydrological cycle to global warming. J Clim, 2006, 19: 5686-5699

Open Access This article is distributed under the terms of the Creative Commons Attribution License which permits any use, distribution, and reproduction in any medium, provided the original author(s) and source are credited. 